\title{
Total Phenolic Content and Antioxidant Activity of Different Extracts of Cordia sebestena L. Leaves
}

\author{
Ni Putu Ermi Hikmawanti ${ }^{1,2}$, Endang Hanani ${ }^{1,2, *}$, Yuni Sapitri ${ }^{2}$, Wulan Ningrum ${ }^{2}$
}

\section{Ni Putu Ermi Hikmawanti ${ }^{1,2}$, Endang Hanani ${ }^{1,2, *}$, Yuni Sapitri ${ }^{2}$, Wulan Ningrum ${ }^{2}$}

'Department of Pharmacognosy and Phytochemistry, Universitas Muhammadiyah Prof. DR. HAMKA JI. Delima II/IV Klender, Jakarta 13460, INDONESIA.

${ }^{2}$ Faculty of Pharmacy and Sciences, Universitas Muhammadiyah Prof. DR. HAMKA JI. Delima II/IV Klender, Jakarta 13460, INDONESIA

\section{Correspondence}

\section{Endang Hanani}

Department of Pharmacognosy and Phytochemistry, Faculty of Pharmacy and Sciences, Universitas Muhammadiyah Prof. DR. HAMKA JI. Delima II/IV Klender, Jakarta 13460, INDONESIA.

Phone No: +62 811881719 ;

E-mail: hananien@yahoo.com

History

- Submission Date: 24-04-2020;

- Review completed: 22-05-2020;

- Accepted Date: 08-07-2020.

DOI : 10.5530/pj.2020.12.180

Article Available online

http://www.phcogj.com/v12/i6

Copyright

(C) 2020 Phcogj.Com. This is an openaccess article distributed under the terms of the Creative Commons Attribution 4.0 International license.

\section{ABSTRACT}

Background: Cordia sebestena L. (Boraginaceae) wildly planted in Jakarta, Indonesia. The secondary metabolites of plants have biological and pharmacological activities, such as antioxidant. The antioxidant activity of plants might be due to their phenolic compounds. Objective: To determine the total phenolic content and evaluate the antioxidant activity of C. sebestena leaves extracts ( $n$-hexane, dichloromethane, ethyl acetate, and $70 \%$ ethanol). Materials and Methods: The total phenolic content was determined using spectrophotometric methods with a Folin-Ciocalteu reagent. The antioxidant activity of the extracts was determined by its ability to inhibit DPPH radicals through $I_{50}$ values $(\mathrm{ppm})$. Results: The highest total phenolic content $(167.61 \pm 0.56 \mathrm{mg} \mathrm{GAE} / \mathrm{g})$ and best antioxidant activity $(31.41 \mathrm{ppm})$ were found in $70 \%$ ethanol extract of $C$. sebestena compared to other extracts (ethyl acetate > dichloromethane $>n$-hexane). Conclusion: The $C$. sebestena leaves have a good potential as a source of natural antioxidant, and further research, is recommended to evaluate the antioxidant activity using another method.

Key words: Boraginaceae, Cordia sebestena, DPPH, Folin-Ciocalteu.

\section{INTRODUCTION}

Cordia sebestena L. (Boraginaceae) is an original plant from Northern South America and distributed in Brazil, Costa Rica, Bahamas, and Jamaica. Now, the plant is planted in many tropical and subtropical countries. In Jakarta, Indonesia, they are planted as an ornamental plant. In Nigeria, this plant is used for the treatment of gastrointestinal disorders. ${ }^{1}$ The leaves also used in the treatment of bronchitis, fever, cough, and influenza. ${ }^{2}$ C. sebestena has pharmacological activity, such as hepatoprotective, ${ }^{3}$ hypoglycaemic, hypolipidemic, antioxidant, ${ }^{4}$ antidiabetic, antibacterial, ${ }^{2}$ anti-inflammatory, and analgesic. ${ }^{5,6}$

The antioxidant is a molecule that significantly inhibits the oxidation of the other substance, although it presents in low concentration. Antioxidants are responsible for defence mechanisms to protect the body from damage to oxidation reactions. Antioxidants react with free radicals and other reactive oxygen species in the body so it can inhibit the oxidation process. ${ }^{\text {? }}$ Antioxidant has already been found in plant material and supplements. The natural antioxidants obtained from plants are greater benefit compare to the synthetic one. ${ }^{8}$ Synthetic antioxidants have genotoxic effects, whereas the use of natural plantbased antioxidants is considered safer due to fewer side effects. ${ }^{9}$

Secondary metabolites from plants have important biological and pharmacological activities, such as anti-oxidative, anti-allergic, antibiotic, hypoglycaemic. ${ }^{10}$ Polyphenolic bioactive compounds have a characteristic aromatic structure, which can be classified into fifteen groups according to the basic part of their molecule, for example phenolics, phenolic acid, flavonoids, anthocyanins, quinones, catechins, tannins, etc. ${ }^{11}$ Antioxidants from secondary metabolites of plants react with radicals and convert them into more stable products. Natural antioxidant compounds include phenolics, flavonoids, carotenoids, catechins, $\beta$-carotene, cinnamic acid, folic acid, ascorbic acid, tocopherols, etc. ${ }^{7,12}$ The strong antioxidant activity of a plant is related to the phenolic compounds contained therein. It help protect the body cell against oxidative damage caused by free radicals. ${ }^{13}$ Total antioxidant capacity (TAC) in plant-based foods and medicinal plants is evaluated to determine their antioxidant properties. ${ }^{14}$

Although the various study has been conducted to investigation the pharmacological activities of C. sebestena, chemical identification for certain compositions responsible for the biological activity of plants are important to investigate. The study aim was to determine the total phenolic content in various extracts of the species C. sebestena using spectrophotometric methods, as well as to evaluate the antioxidant activity of plant extracts using in vitro DPPH assay.

\section{MATERIALS AND METHODS}

\section{Collection and authentication of plant}

The C. sebestena L. leaves were collected in June 2019 from the East Jakarta area, Indonesia. The plant was identified in Herbarium Bogoriense, Biology Research Centre, Indonesian Institute of Sciences/Lembaga Ilmu Pengetahuan Indonesia (LIPI), Cibinong. The specimen was deposited in Pharmacognosy Laboratory, Faculty of Pharmacy 
and Sciences, Universitas Muhammadiyah Prof. DR. HAMKA, Jakarta. The $C$. sebestena $\mathrm{L}$. fresh leaves were washed under running tap water. Then, the leaves were dried for a few days and were made into powder.

\section{Chemicals and reagents}

$n$-Hexane, dichloromethane (DCM), ethyl acetate, and ethanol in analytical grade as extraction solvents were form Merck (Darmstadt, Germany). 2,2-diphenyl-1picrylhydrazyl (DPPH) free radical, FolinCiocalteu (F-C) reagent, Gallic acid, and Quercetin were from SigmaAldrich Co. (St Louis, USA).

\section{Preparation of extracts}

The dried powder $(250 \mathrm{~g})$ was extracted in various solvents such as $n$-hexane, dichloromethane (DCM), ethyl acetate, and $70 \%$ ethanol according to their increasing strength of polarity, by cold maceration (2 times, 24 hours). The extracts were filtered through a filter paper. The residue was further repeated once with the same solvent. Each filtrate was evaporated using a vacuum rotary-evaporator N-1200 BS series (EYELA, Shanghai, China) at $40{ }^{\circ} \mathrm{C}$. The percentage yield of $n$-hexane (HECS), dichloromethane (DECS), ethyl acetate (EAECS) and ethanolic (EECS) extracts of $C$. sebestena leaves were calculated.

\section{Physicochemical evaluation}

Physicochemical characteristics of each extract such as water content, total-ash value, and loss on drying were performed according to the Indonesian Herb Pharmacopoeia, ${ }^{15}$ and WHO guidelines on the quality control methods for the medicinal plant materials. ${ }^{16}$

\section{Phytochemical investigation}

The presence of secondary metabolites (viz., alkaloids, flavonoids, phenolics, etc.) of the extracts were qualitatively identified using the standard procedures describes in the Harborne, ${ }^{17}$ Indonesian Herb Pharmacopoeia, ${ }^{15}$ and Hanani. ${ }^{18}$

\section{Determination of total phenolics content}

Total phenolic content (TPC) was measured by colorimetry according to the Folin-Ciocalteu method ${ }^{19}$ using gallic acid as the standard. Samples $(300 \mu \mathrm{L})$ were mixed vigorously with $1.5 \mathrm{~mL}$ of the FolinCiocalteu reagent (diluted ten times). After $3 \mathrm{~min}, 1.2 \mathrm{~mL}$ of sodium carbonate solution $(7,5 \%)$ was added to the mixture. The mixed solution was then immediately diluted to the required volume (10 $\mathrm{mL}$ ) with distilled water. The reaction mixture was incubated at room temperature $\left(25^{\circ} \mathrm{C}\right)$ for $30 \mathrm{~min}$. The absorbance was measured at 760 $\mathrm{nm}$ with a spectrophotometer UV-Vis (UV-1601 Series, Shimadzu, Kyoto, Japan). Gallic acid solution with concentration ranging from 18-60 ppm was used for calibration. A dose-response linear regression was generated by using the gallic acid standard absorbance. The total phenolic content was expressed as gallic acid equivalent (mg of GAE/g of extract). The estimation was performed in triplicate, and the results were expressed as mean $\pm \mathrm{SD}$.

\section{Antioxidant activity}

Antioxidant activity of the extracts was measure base on the DPPH (1,1diphenyl-2-picrylhydrazyl) assay. ${ }^{20}$ Each extract stock solution was prepared at a concentration of $1000 \mathrm{ppm}$ in methanol. A quercetin stock solution was prepared at a concentration of $100 \mathrm{ppm}$ in methanol. In the analytical procedure, the measurements of antioxidant activity were performed at four points of concentration (including extracts and quercetin standard solution). Briefly, $1.0 \mathrm{~mL}$ of freshly DPPH solution $(0.2 \mathrm{mM})$ in methanol was reacted with $1.0 \mathrm{~mL}$ of extract or quercetin solution. The final volume was made $5 \mathrm{ml}$ with methanol. The mixture is homogenized incubated in the dark (test tubes were protected from light by covering with aluminium foil) for $30 \mathrm{~min}$ at room temperature. After $30 \mathrm{~min}$, the absorbance of the decolorizing (from deep violet to light yellow) process was read at $515 \mathrm{~nm}$ using a spectrophotometer UV-Vis (UV-1601 Series, Shimadzu, Kyoto, Japan). For comparison, the activity of the quercetin standard was evaluated. The control solution contains the same volume of methanol and DPPH without any extract or reference quercetin. Methanol was served as blank. The percentage scavenging of the DPPH free radical was measured by using the following equation [1]:

$$
\% \text { Inhibition }=(\text { Ac-As }) / A c) \times 100
$$

Where, Ac is the absorbance of the control solution; As is the absorbance in the presence of the sample of the extracts. All tests were performed in triplicates, and the results were averaged. The sample concentrations ( $\mathrm{x}$ ) were plotted against the inhibition ratios $(y)$, and then the regression line equation $(y=b x \pm a)$ was obtained. The calculation of $50 \%$ of the inhibition concentration of DPPH radical is obtained by entering 50 on $\mathrm{y}$ in the regression line equation, so $\mathrm{x}$ is the $\mathrm{IC}_{50}$ value.

\section{Statistical analysis}

Three replications of each treatment were performed for all experiments. Microsoft $^{\oplus}$ Excel 365 (Microsoft Office Software 2016, USA) was used to elucidate the $\mathrm{IC}_{50}$ results of antioxidant activity.

\section{RESULTS}

C. sebestena leaves were extracted by maceration method using solvents with different polarity levels. The extraction yield can be seen in Table 1 .

Phytochemical screening aims to identify the presence of chemical substances in the sample qualitatively. Based on the results in Table 2, it can be concluded that phenolics, flavonoids, alkaloids, and tannins compounds are present in all extracts. Meanwhile, saponins compounds are found in EECS. The HECS showed the least number of phytochemicals.

TPC of extracts was determined by Folin-Ciocalteu (F-C) assay using gallic acid as a standard of phenolic compound. The colour product between $\mathrm{F}-\mathrm{C}$ and phenolic reaction is measured at a maximum wavelength of $767.0 \mathrm{~nm}$. A linear calibration curve of Gallic acid ( $y=$ $0.0131 \mathrm{x}+0.0041)$, in the range of $18-60 \mathrm{ppm}$ with the coefficient of

Table 1: The extraction yield and physicochemical characteristic of $C$. sebestena leaves extracts.

\begin{tabular}{ccccc}
\hline \multirow{2}{*}{ Type of extracts } & \multicolumn{3}{c}{ Results } \\
\cline { 2 - 5 } & Extraction yield $(\%, w / w)$ & Water content $(\%, \mathrm{v} / \mathrm{w})$ & Total ash $(\%, w / w)$ & Loss of drying $(\%, w / w)$ \\
\hline HECS & 4.46 & 1.53 & 1.45 & 2.13 \\
DECS & 4.39 & 1.92 & 2.52 & 2.27 \\
EAECS & 4.73 & 2.47 & 0.46 & 2.68 \\
EECS & 15.39 & 25.25 & 16.31 & 25.85 \\
\hline
\end{tabular}

Note: HECS = $n$-Hexane Extract of C. sebestena DECS = Dichloromethane Extract of C. sebestena: EAECS = Ethyl Acetate Extract of C. sebestena; EECS = Ethanolic Extract of C. sebestena. 
determination $\left(\mathrm{R}^{2}\right)$ value of 0.9998 , was obtained. TPC of the extracts of C. sebestena is demonstrated in Figure 1. The highest total phenolic were found in EECS at $167.61 \pm 0.56 \mathrm{mg} \mathrm{GAE} / \mathrm{g}$ extract, approximately 2.5 -fold more than the HECS; it was following with the highest highest extraction yield of EECS at 15.39\% (Table 1).
DPPH radical-scavenging capacity of the extracts was measured using $\mathrm{IC}_{50}$ value. It defined as the concentration of antioxidants required to decrease the $\mathrm{DPPH}$ radical by $50 \%$. The lower value of $\mathrm{IC}_{50}$ indicates the high antioxidant activity of the extract. The $\mathrm{IC}_{50}$ amount of various plant extracts and positive controls was shown in Figure 2.

Table 2: Phytochemical screening of $C$. sebestena leaves extracts.

\begin{tabular}{ccccc}
\hline \multirow{2}{*}{ Compounds } & \multicolumn{5}{c}{ Type of extracts } & EECS \\
\cline { 2 - 5 } & HECS & DECS & EAECS & + \\
\hline Phenolics & + & + & + & + \\
Flavonoids & + & + & + & + \\
Tannins & + & + & + & + \\
Alkaloids & + & + & + & + \\
Saponins & - & - & + & + \\
Steroids & - & + & + & + \\
Triterpenoids & - & + & & + \\
\hline
\end{tabular}

Note: $(+)=$ detected, $(-)=$ no detected

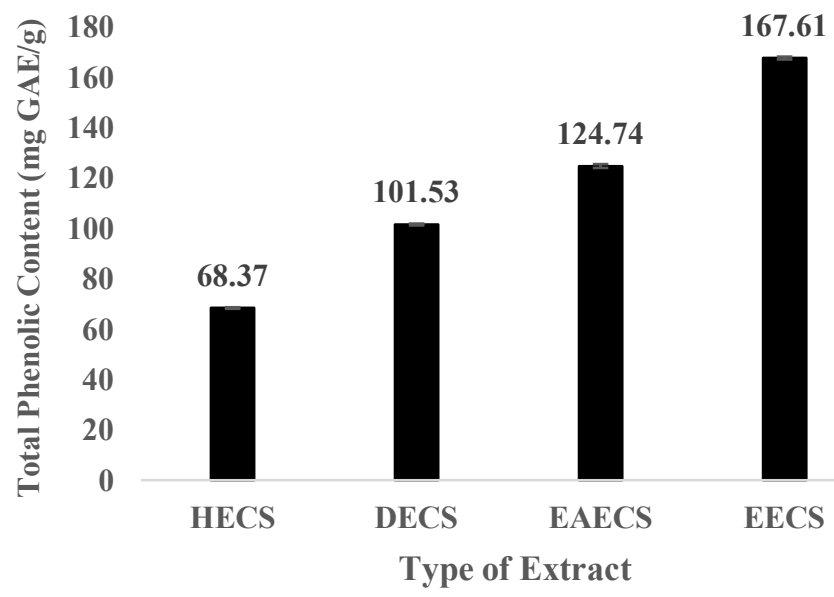

Figure 1: Total phenolics content of $C$. sebestena leaves extracts. Note: Data are expressed as mean $\pm \operatorname{SD}(n=3)$.

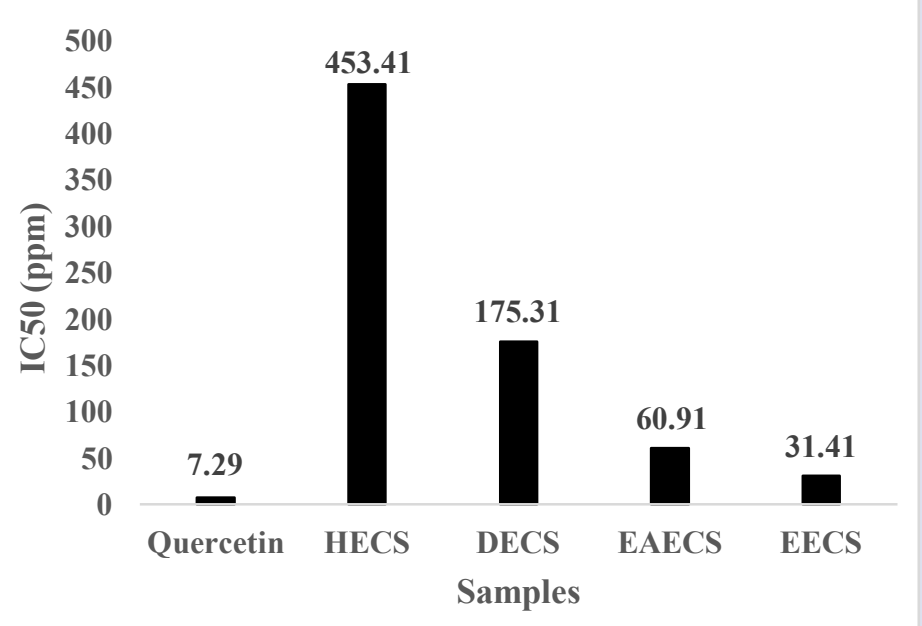

Figure 2: $I C_{50}$ value against DPPH radical of $C$. sebestena leaves extracts compared to quercetin as control. Note: Data are expressed as mean $\pm S D(n=3)$. 


\section{DISCUSSION}

The yields of extraction by various solvents of C. sebestena leaves increased in the following order: DECS < HECS < EAECS < EECS. The highest yield was found in EECS (15.39\%), whereas HECS, DECS, and EAECS mostly about $4.39-4.73 \%$. It shows that polar compounds dominate $C$. sebestena leaves. The high percentage of extract yield in EECS can also be caused by the content of non-phenolic polar compounds such as carbohydrates and glycosides, which also dissolve during the extraction process.

When the plant extract is burned, they leave inorganic ash in enough limits. The total ash usually consists mainly of carbonates, phosphates, silicates, and silica. Ash values of HECS, DECS, and EAECS were found $<3 \%$, which indicates that the extracts are clean and free from dirt and sandy material. Meanwhile, EECS shows a high total ash value of $16.31 \%$. Hanani et al. ${ }^{21}$ reported that ash values of powdered leaves of C. sebestena were found $13.6 \%$. The amount and composition of ash remaining after the combustion of plant material vary considerably according to the part of the plant, treatment, age, location etc. ${ }^{22}$

One of the factors that affect the quality of an extract is its water content. Water content that is too high in the extract will cause the stored power to be short. The water content of HECS, DECS, and EAECS were found $<5 \%$. Whereas, in EECS found high water content (25.25\%). These results indicate that the EECS includes the criteria for thick extract (5-30\%). ${ }^{15}$ Hydroethanolic (70\%) as an extraction solvent has higher polarity than absolute ethanol because of the $30 \%$ water content in it. ${ }^{23}$ However, ethanol with a concentration of $70 \%$ as a solvent causes the water content obtained is greater, compared to using absolute ethanol. Moisture content can affect the physical and physicochemical properties of a material. ${ }^{24}$ The high percentage of the water content of EECS is also due to the limitations of the vaporizers that we used. For further evaporation, a relatively high temperature is needed, but this is feared to cause the decomposition of compounds in EECS. Adeosun et al. ${ }^{25}$ reported that C. sebestena leaves which extracted by hydro-distillation contained volatile compounds of $0.05 \%$ with the main chemical component including 2-nonen-1-ol (25.7\%), bis(2-methylpropyl) hexanedioc acid ester (17.8\%), butanedioc acid, dimethyl ester (11.4\%), heptadecane (10.2\%), phytol (7.6 \%) and bis(2-metylpropyl)butanedioc acid ester (4.5\%). This volatile oil also evaporates during the drying procedure, so that the loss drying value in the EECS obtained is also high (25.85\%) (Table 1.).

Phytochemical screening results in this study are following previous studies by Hanani et al..$^{21}$ that ethanolic extract of $C$. sebestena leaves showed alkaloids, phenols, flavonoids, tannins, saponin, steroids, and terpenoids. It can be implied that the phytochemical compounds in C. sebestena leaves dissolved better in $70 \%$ ethanol solvent. The composition and quantity of phytochemicals from plant extract and its biological activity are affected by the applied extraction solvent. Ethanol-water as solvent extraction was more efficient and seemed to be most suitable for extraction the bioactive compounds, especially phenolics, than absolute alcohol because of the different polarity of both solvents. ${ }^{23}$ Besides, ethanol or ethanol-water is safe for human consumption. ${ }^{26}$

Phenolics are a compound that has one or more hydroxyl groups on the aromatic ring. The extraction of phenolic compounds depends mostly on the chemical properties of the phenolics, including molecular structure, polarity, concentration, number of aromatic rings, and hydroxyl groups. The choice of extraction solvents will influence the yields of phenolics extracted. The solvents include water, acetone, ethyl acetate, alcohols (methanol, ethanol, and propanol) and their mixtures. Phenolic acids were extracted using organic solvents such as diethyl ether, ethyl acetate, acetone, or chloroform. ${ }^{27}$
The Folin-Ciocalteu (F-C) method is based on the reduction of a phosphotungstic-phosphomolybdate complex by phenolics in alkaline medium to blue reaction products. The high phenolics content in EECS may have contributed towards its antioxidant and related activity. Phenolic substance tends to be water-ethanol soluble, since they most frequently occur combined with sugar as glycosides. ${ }^{17}$ These results indicated that the total content of phenolic compounds in different extracts was depended on the type of extracts, i.e., the polarity of extraction solvents. These results are similar to those reported by Mohsen and Ammar. ${ }^{28}$

Antioxidants are compounds that can inhibit or prevent the oxidation of oxidizable materials, which can cause oxidative stress by scavenging free radicals. Oxidative stress is related to the development of chronic degenerative diseases, include atherosclerosis, diabetes mellitus, Alzheimer's disease, neurodegenerative diseases, hypertension, etc. Free radical scavenging capacity is commonly determined by DPPH assay because it is technically simple and accurate. This assay is valid to quantify antioxidant compounds with hydrophilic or lipophilic properties. $^{12}$

The $\mathrm{DPPH}^{\star}$ radical (deep purple colour) is one of the few stable organic nitrogen radicals. This assay is based on the measurement of the reducing ability of antioxidants toward $\mathrm{DPPH}^{\star} .{ }^{29}$ When a DPPH solution is mixed with an antioxidant that can donate a hydrogen atom, then this gives rise to the reduced form with the loss of this violet colour. In this study, the DPPH radical scavenging activity of various C. sebestena extracts increased in the following order: HECS $<$ DECS $<$ EAECS $<$ EECS. The EECS $\left(\mathrm{IC}_{50}=31.41 \mathrm{ppm}\right)$ has the highest antioxidant activity compared to the other extracts. EECS has the potential to be a powerful antioxidant because it has an $\mathrm{IC}_{50}$ value of a DPPH radical $<50 \mathrm{ppm} .{ }^{30}$ Extracts obtained using more polar extraction solvents are more effective radical scavengers then those using less polar solvents.

The phytochemicals in C. sebestena, which might be responsible for the scavenging activity is phenolic. Phenolic compounds such as gallic acid, trans-resveratrol, quercetin, and its glycoside rutin have been reported to have strong antioxidant activity ${ }^{12}$ that act as free radical acceptors. They interfere with the oxidation of lipids and other molecules by the rapid donation of a hydrogen atom to radicals. Phenolic compounds as an antioxidant have the ideal chemical structure to reduce free radicals because they have: (1) hydroxyl groups that are prone to donate a hydrogen atom or an electron to a free radical; (2) extended conjugated aromatic system to delocalize an unpaired electron. Besides that, they also have a metal chelation potential. ${ }^{13,26}$

\section{CONCLUSION}

In general, extraction yield, TPC, and antioxidant activity increased with increasing polarity of extraction solvent. Ethanol extract (EECS) contains more phenolics compounds and higher antioxidant activity than the other extract ( $n$-hexane, dichloromethane, and ethyl acetate). It is concluded that phenolics from the ethanol extract of $C$. sebestena are good potential as a source of natural antioxidants. For further research, it is recommended to evaluate the antioxidant activity using another method.

\section{ACKNOWLEDGEMENTS}

The authors are very much thank-full to Dr. apt. Hadi Sunaryo, M.Si., as Dean of Faculty of Pharmacy and Sciences, Universitas Muhammadiyah Prof. DR. HAMKA, Klender, East Jakarta, Indonesia for providing laboratory facilities and support to carry out the research work.

\section{CONFLICTS OF INTEREST}

The authors declare no conflicts of interest. 


\section{REFERENCES}

1. Trivedi $\mathrm{MH}$, Ramana KV, Rao CV. Evaluation of antiulcer activity of Cordia sebestena L. root. Int J Pharm Pharm Res. 2015;4(1):167-70.

2. Oza MJ, Kulkarni YA. Traditional uses, phytochemistry and pharmacology of the medicinal species of the genus Cordia (Boraginaceae). J Pharm Pharmacol. 2017;69:755-89.

3. Pradeep KR, Balavardhan SN. Hepatoprotective and antioxidant activity of Cordia sebestena in animal model. J Glob Trends Pharm Sci. 2015;6(1):2472-8

4. Sarathchandiran I, Gnanavel M. Investigation on hypoglycemic, antioxidant and Hypolipidemic activity of ethanolic leaf extract of Cordia sebestena in streptozotocin-induced diabetic rats. Int J Res Pharm Sci. 2013;4(3):336-43.

5. Trivedi MH, Ramana KV, Rao CV. Evaluation of anti inflammatory and analgesic activities of Cordia sebestena L. roots. Indo Am J Pharm Res. 2015;5(08):2765-8.

6. Sunaryo H, Siska S, Hanani E, Anindita R, Yanti N. Evaluation of analgesic and anti-inflammatory activities of ethanolic extract of Cordia sebestena L. Eur Pharm J. 2019;66(2):1-5.

7. Moharram HA, Youssef MM. Methods for determining the antioxidant activity A Review. Alexandria J Food Sci Technol. 2014;11(1):31-42.

8. Rohman A, Riyanto S, Yuniarti N, Saputra WR, Utami R, Mulatsih W. Antioxidant activity, total phenolic, and total flavonoid of extracts and fractions of red fruit (Pandanus conoideus Lam). Int Food Res J. 2010;17(1):97-106.

9. Chen C, Pearson AM, Gray JI. Effects of synthetic antioxidants (BHA, BHT and PG) on the mutagenicity of IQ-like compounds. Food Chem. 1992;43(3):177-83.

10. Borneo R, León AE, Aguirre A, Ribotta P, Cantero JJ. Antioxidant capacity of medicinal plants from the Province of Córdoba (Argentina) and their in vitro testing in a model food system. Food Chem. 2009;112:664-70.

11. Evans WC. Trease and Evans Pharmacognosy. $16^{\text {th }}$ edition. Toronto: Elsevier; 2009.

12. Ndhlala AR, Moyo M, Van Staden J. Natural antioxidants: Fascinating or Mythical Biomolecules? Molecules. 2010;15:6905-30.

13. Kähkönen MP, Hopia Al, Vuorela HJ. Antioxidant activity of plant extracts containing phenolic compounds. J Agric Food Chem. 1999;47(10):3954-62.

14. Pellegrini N, Serafini M, Colombi B. Total antioxidant capacity of plant foods, beverages and oils consumed in Italy assessed by three different in vitro assays. J Nutr. 2003;133(9):2812-9.

15. Ministry of Health Republic of Indonesia. Farmakope Herbal Indonesia (Indonesian Herb Pharmacopoeia). 1st Edition. Jakarta: Ministry of Health Republic of Indonesia; 2008.
16. World Health Organization. Quality Control Methods for Medicinal Plant Materials. Geneva, Switzerland: World Health Organization; 1998.

17. Harborne J. Metode Fitokimia: Penentuan Cara Modern Menganalisis Tumbuhan (In Bahasa). (Padmawinata, Kosasih; Soediro I, ed.). Bandung: ITB Press; 1987.

18. Hanani E. Analisis Fitokimia (In Bahasa). Jakarta: Buku Kedokteran EGC; 2015.

19. Yang J, Paulino R, Janke-Stedronsky S, Abawi F. Free-radical-scavenging activity and total phenols of noni (Morinda citrifolia L.) juice and powder in processing and storage. Food Chem. 2007;102(1):302-8.

20. Nagmoti DM, Khatri DK, Juvekar PR, Juvekar AR. Antioxidant activity free radical-scavenging potential of Pithecellobium dulce Benth seed extracts. Free Radicals Antioxidants. 2012;2(2):37-43.

21. Hanani E, Soewandi SHW, Hayati;, Revita N. Pharmacognostical and preliminary phytochemical evaluation of Cordia sebestena L. Pharmacogn J. 2019;11(5):1100-5.

22. Tambe SS., Deore S., Fatima S., Kadam V. Determination of ash value of some plants of marathwada region in. Int J Pharm Reseacrh Bio-Sciences. 2012;1(3):337-46.

23. Tiwari $P$, Kumar B, Kaur M, Kaur G KH. Phytochemical screening and extraction: A review. Int Pharm Sci. 2011;1(1):98-106.

24. Yulianti, Susilo B, Yulianingsih R. Influence of extraction time and ethanol solvent concentration to physical-chemical properties Stevia leaf extract (Stevia rebaudiana Bertoni M.) using microwave assisted extraction Methods. J Bioproses Komod Trop. 2014;2(1):35-41.

25. Adeosun CB., Bamigbade O, Osho A, Atolani O. Volatile composition of the leaf, flower and fruit of Cordia sebestena (L.). J Essent Oil-Bearing Plants. 2015;18(4):976-81.

26. Dai J, Mumper RJ. Plant phenolics: Extraction, analysis and their antioxidant and anticancer properties. Molecules. 2010;15(10):7313-52.

27. Khoddami A, Wilkes MA, Roberts TH. Techniques for analysis of plant phenolic compounds. Molecules. 2013;18(2):2328-75

28. Mohsen SM, Ammar ASM. Total phenolic contents and antioxidant activity of corn tassel extracts. Food Chem. 2009;112(3):595-8.

29. Singh S, Singh RP. In vitro methods of assay of antioxidants: An overview. Food Rev Int. 2008;24(4):392-415.

30. Molyneux P. The use of the stable free radical diphenylpicryl-hydrazy (DPPH) for estimating antioxidant activity. Songklanakarin J Sci Technol. 2004;26(2):211-9.

\section{GRAPHICAL ABSTRACT}

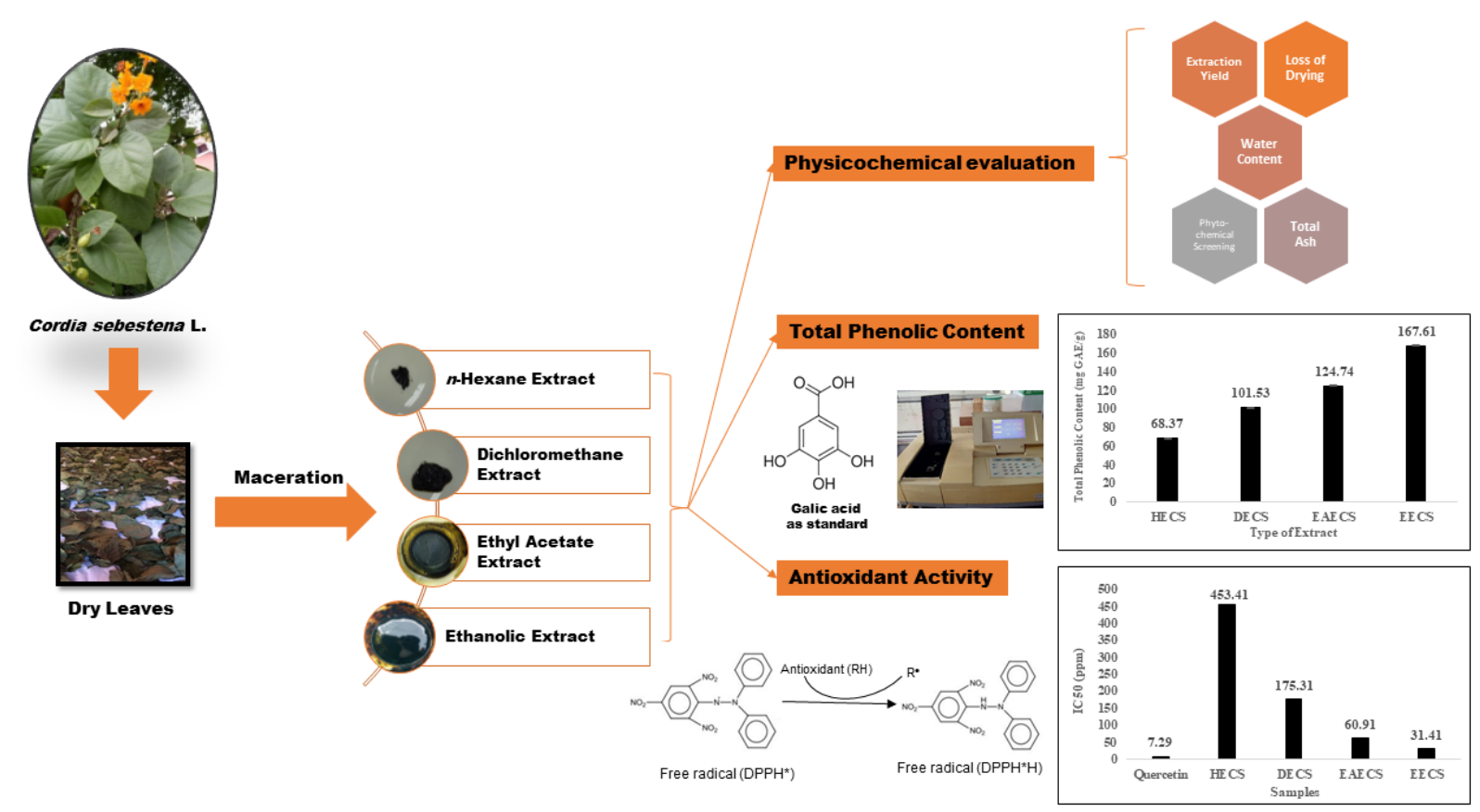




\section{SUMMARY}

- Cordia sebestena L. (Boraginaceae) have biological and pharmacological activities, such as antioxidant.

- This research was performed to determine the total phenolic content and antioxidant activity of some $C$. sebestena leaf extracts.

- The C. sebestena leaves have a good potential as a source of natural antioxidants.

\section{ABOUT AUTHORS}

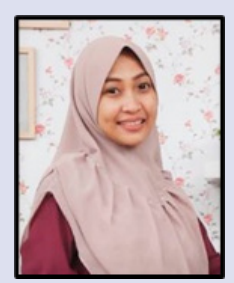

Ni Putu Ermi Hikmawanti: Lecturer and researcher at Faculty of Pharmacy and Sciences, Universitas Muhammadiyah Prof. DR. HAMKA, Klender, Jakarta 13460, Indonesia.

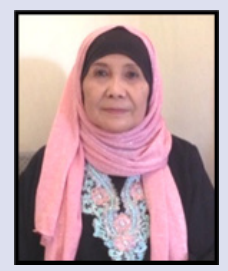

Endang Hanani: Lecturer and researcher at Faculty of Pharmacy and Sciences, Universitas Muhammadiyah Prof. DR. HAMKA, Klender, Jakarta 13460, Indonesia.

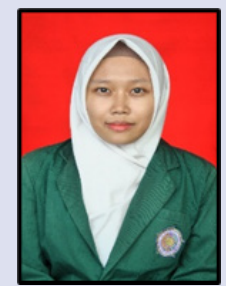

Yuni Sapitri: Graduate student at Faculty of Pharmacy and Sciences, Universitas Muhammadiyah Prof. DR. HAMKA, Klender, Jakarta 13460, Indonesia.

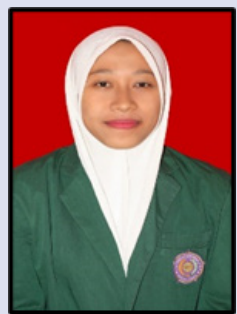

Wulan Ningrum: Graduate student at Faculty of Pharmacy and Sciences, Universitas Muhammadiyah Prof. DR. HAMKA, Klender, Jakarta 13460, Indonesia.

Cite this article: Hikmawanti NPE, Hanani E, Sapitri Y, Ningrum W. Total Phenolic Content and Antioxidant Activity of Different Extracts of Cordia sebestena L. Leaves. Pharmacogn J. 2020;12(6):1311-6. 